OPEN ACCESS

Edited by:

Lorenzo Angeletti, Institute of Marine Science, National

Research Council (CNR), Italy

Reviewed by:

Americo Montiel,

Universidad de Magallanes, Chile

Miguel Angel Ahumada-Sempoal,

University of the Sea, Mexico

*Correspondence:

Pei-Yuan Qian

boqianpy@ust.hk

Specialty section:

This article was submitted to

Deep-Sea Environments and Ecology,

a section of the journal

Frontiers in Marine Science

Received: 21 July 2021 Accepted: 13 September 2021

Published: 11 October 2021

Citation:

Perez $M$, Sun J, Xu Q and

Qian P-Y (2021) Structure

and Connectivity of Hydrothermal

Vent Communities Along

the Mid-Ocean Ridges in the West

Indian Ocean: A Review.

Front. Mar. Sci. 8:744874

doi: $10.3389 /$ fmars.2021.744874

\section{Structure and Connectivity of Hydrothermal Vent Communities Along the Mid-Ocean Ridges in the West Indian Ocean: A Review}

\author{
Maëva Perez ${ }^{1,2,3}$, Jin Sun ${ }^{4}$, Qinzeng $X u^{5}$ and Pei-Yuan Qian ${ }^{1,2 *}$ \\ ${ }^{1}$ Department of Ocean Science and Hong Kong Branch of Southern Marine Science and Engineering Guangdong \\ Laboratory (Guangzhou), The Hong Kong University of Science and Technology, Kowloon, Hong Kong SAR, China, \\ ${ }^{2}$ Southern Marine Science and Engineering Guangdong Laboratory, Guangzhou, China, ${ }^{3}$ Département des Sciences \\ Biologiques, Université de Montréal, Montreal, QC, Canada, ${ }^{4}$ Institute of Evolution and Marine Biodiversity, Ocean University \\ of China, Qingdao, China, ${ }^{5}$ MNR Key Laboratory of Marine Eco-Environmental Science and Technology, First Institute \\ of Oceanography, Ministry of Natural Resources, Qingdao, China
}

To date, 13 biologically active hydrothermal vent (HTV) fields have been described on the West Indian Ocean ridges. Knowledge of benthic communities of these vent ecosystems serves as scientific bases for assessing the resilience of these ecosystems under the global effort to strike an elegant balance between future deep-sea mining and biodiversity conservation. This review aims to summarize our up-to-date knowledge of the benthic community structure and connectivity of these Indian vents and to identify knowledge gaps and key research questions to be prioritized in order to assess the resilience of these communities. The HTVs in the West Indian Ocean are home to many unique invertebrate species such as the remarkable scaly-foot snail. While distinct in composition, the macrofaunal communities of the Indian HTVs share many characteristics with those of other HTVs, including high endemism, strong zonation at the local scale, and a simple food web structure. Furthermore, Indian vent benthic communities are mosaic compositions of Atlantic, Pacific, and Antarctic HTV fauna possibly owning to multiple waves of past colonization. Phylogeographic studies have shed new light into these migratory routes. Current animal connectivity across vent fields appears to be highly influenced by distance and topological barriers. However, contrasting differences in gene flow have been documented across species. Thus, a better understanding of the reproductive biology of the Indian vent animals and the structure of their population at the local scale is crucial for conservation purposes. In addition, increased effort should be given to characterizing the vents' missing diversity (at both the meio and micro-scale) and elucidating the functional ecology of these vents.

Keywords: conservation, ecology, chemosynthesis, gene-flow, mining, Indian Ocean ridge, biodiversity, knowledge gaps

Abbreviations: HTV, hydrothermal vent; SWIR, Southwest Indian Ridge; CIR, Central Indian Ridge; SEIR, Southeast Indian Ridge; CR, Carlsberg Ridge. 


\section{INTRODUCTION}

The International Seabed Authority (ISA) has been working with stakeholders and lawmakers to draft regulations governing seabed mining by 2023 (International Seabed Authority, 2018). Given the growing interest in mining polymetallic deposits at hydrothermal vents (HTVs), assessing the vulnerability of their biological communities, which are predicted to hold valuable natural products (Thornburg et al., 2010; Van Dover et al., 2018) and play an important role in carbon cycling (Bell et al., 2017), is an urgent and essential task. Mining operations on vent ecosystems are foreseen to have multiple severe consequences (Reed et al., 2015; Ellis et al., 2017; Gollner et al., 2017; Van Dover et al., 2018; Washburn et al., 2019), but specific guidelines for conservation are hard to formulate because of immense knowledge gaps on the ecology of these ecosystems and in particular their natural resilience and connectivity. HTV communities were initially presumed to be highly resilient because of the great variability and unpredictability of the environmental conditions to which they have adapted (Hessler et al., 1988; Juniper and Tunnicliffe, 1997; Sarrazin et al., 1997), but the discovery of slow-growing species (Urcuyo et al., 2007) and highly stable vent communities (Boschen et al., 2015; Du Preez and Fisher, 2018) has challenged these assumptions and highlighted the need for a global assessment of HTV biodiversity. In a recent study, Gollner et al. (2021) assessed 11 confirmed vent fields on the northern Mid-Atlantic Ridge (MAR) by using a combination of criteria set for "Vulnerable Marine Ecosystems" by FAO and "Ecologically or Biologically Significant Areas" by CBD and "Particularly Sensitive Sea Areas" by IMO, and concluded that 10 of those 11 HTV fields met all the criteria for ecosystems in need of protection.

The spreading ridges of the Indian Ocean and their hydrothermal ecosystems (Figure 1) are unique but have less known vent ecosystems than those in the Atlantic and Pacific mid-ocean ridges in terms of their spreading rate (Müller et al., 2008; Beaulieu, 2015), mineral composition (German et al., 2016), and carbon input from the surface (Harms et al., 2021). Indian Ocean spreading ridge vent ecosystems have been hypothesized to serve as a corridor of connectivity between Atlantic and Pacific vent fauna (Ramirez-Llodra et al., 2007; Bachraty et al., 2009; Moalic et al., 2012; Rogers et al., 2012).

The mid-ocean ridges of the Indian Ocean display contrasting spreading rates that range from intermediate $(\sim 80 \mathrm{~mm} /$ year $)$ to ultraslow ( $<20 \mathrm{~mm} /$ year). Slower spreading at mid-ocean ridges usually translates to less intense hydrothermal activity (Baker et al., 1996; German and Parson, 1998), but this correlation is not always true at ultraslow spreading ridges (Dick et al., 2003; Snow and Edmonds, 2007; German et al., 2016) as evidenced by the discovery of large active HTV fields (Edmonds et al., 2003; Connelly et al., 2007; Tao et al., 2009; Kinsey and German, 2013). At ultraslow spreading ridges, hydrothermal fluids penetrate deeper in the crust, possibly below the Moho boundary (Tao et al., 2020), and hydrothermal circulation is more stable (Baker et al., 2004). It is estimated, for instance, that hydrothermal activity at the now inactive vent site Mount Jourdanne had lasted for more than 50,000 years. Given these unique characteristics, polymetallic sulfide deposits may be more important (German et al., 2016) and richer in copper and gold (German et al., 2016) at the slower-spreading Indian ridges and are thus of greater interest to mining companies. At the same time, their higher stability and lower nutritional resources may render their HTV communities more vulnerable to environmental disturbances (Fjeldsaå and Lovett, 1997; Du Preez and Fisher, 2018).

In this short review, we summarize the current state of knowledge about the community composition and connectivity of HTVs in the West Indian Ocean ridges, focusing mainly on macrofaunal species. Specifically, we aim to address the following questions: (1) How diverse and variable are the HTV communities, and do diversity and variability impact the resilience of these ecosystems? (2) To what extent are the Indian mid-ocean ridges HTV ecosystems connected, and how do these connectivity patterns vary across species? (3) How unique are the characteristics of community composition and connectivity in the West Indian mid-ocean ridges in comparison to vent systems in the other oceans? and (4) What are the knowledge gaps that need to be filled first in order to assess the sustainability of mining operations?

\section{COMMUNITY STRUCTURE}

\section{Diversity and Endemicity}

Macrofaunal communities in the Western Indian Ocean HTVs are akin to other deep-sea chemosynthetically based ecosystems with low species richness but high abundance of individuals (Tsurumi, 2003; Dover and Doerries, 2005; Sarrazin et al., 2015) (see Supplementary Material). Macrofaunal species richness in the HTVs of the Indian Ocean are in the range of what has been observed elsewhere (see Supplementary Material). At the Southwest Indian Ridge (SWIR) and the Central Indian Ridge (CIR), 39 and 37 macrofauna taxa were identified, respectively (Watanabe and Beedessee, 2015; Zhou et al., 2018), whereas between 1 and 116 (21 species on average) were described from other vents worldwide (Bachraty et al., 2009). Dominant macrofaunal species in the Indian Ocean vent ecosystems include the shrimp Rimicaris kairei, the mussel Bathymodiolus marisindicus, the crab Austinograea rodriguezensi, the scalyfoot snail Chrysomallon squamiferum, the snails of the genus Gigantopelta and Alvinichoncha, the stalked barnacle Neolepas marisindica, and the polychaetes Ophryotrocha jiaolongi (SWIR) and Branchipolynoe longqiensis, which are commensal worms in the mantle cavity of B. marisindicus (SWIR).

Like elsewhere, macrofaunal vent communities in the Indian Ocean also possess high endemicity (Ramirez-Llodra et al., 2007; Rogers et al., 2012; Figure 2). The Indian vent communities are also distinct in composition from other oceans because almost all the dominant taxa above are unique to the Indian vents (Hashimoto et al., 2001; Nakamura et al., 2012; Copley et al., 2016; Zhou et al., 2018; Kim et al., 2020). With the restricted distribution of these animals, fragmented habitat, and uncertainties about their demographic fluctuations, the proposed idea was to first place these species preemptively in the IUCN Red List of threatened species (Sigwart J. D. et al., 2019). These 


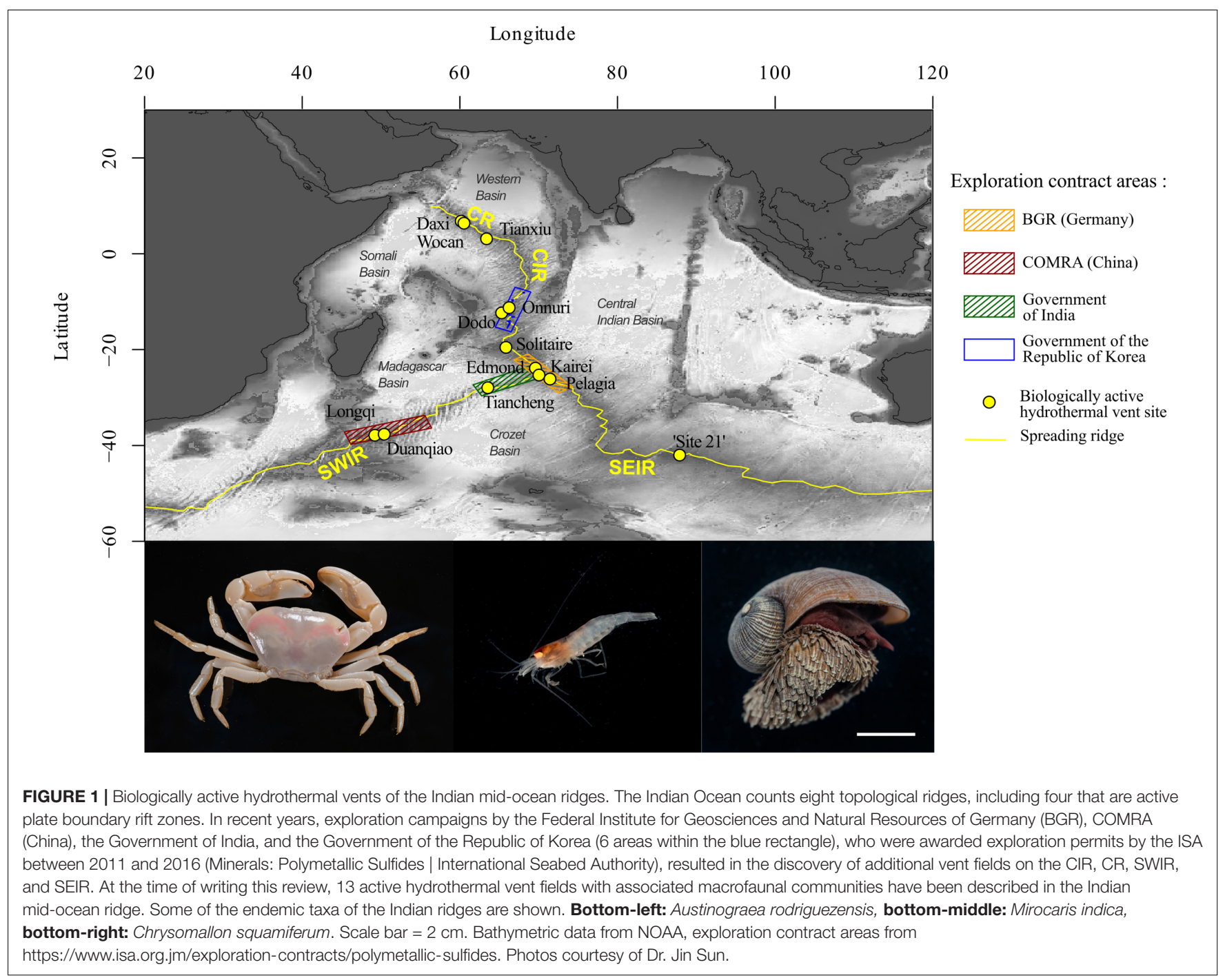

criteria permitted the addition of the scaly-foot snail to that list in 2019 (Sigwart J. et al., 2019). Furthermore, a similar degree of variation in community composition exists within the Indian biogeographic province itself (Figure 2). For instance, roughly a quarter of the macrofaunal vent species found on the SWIR were not found in other vent fields in the Indian Ocean (Zhou et al., 2018), and major differences in species richness and abundance can be observed between sites located even on the same spreading ridge (see section "Community Differences Across Vent Fields").

\section{Spatial Zonation at the Local Scale}

Strong spatial zonation on the scale of a few meters, similar to the situations described for the Juan de Fuca Ridge and East Pacific Rise (EPR) vents (Shank et al., 1998; Sarrazin et al., 1999), was observed in the HTVs of the Indian Ocean (Nakamura et al., 2012; Watanabe and Beedessee, 2015; Copley et al., 2016; Zhou et al., 2018). Invertebrates with strong nutritional reliance on chemosymbionts (e.g., shrimps and mussels) and to a lesser extent various grazers and omnivorous taxa (e.g., crabs and polychaetes) were the dominant macrofauna in high-sulfide environments, whereas suspension feeders such as Actinians cnidarians were found on the periphery of these assemblages (Watanabe and Beedessee, 2015). Studies from other vents suggest that physicochemical parameters (notably temperature and hydrogen sulfide concentration) significantly affect species distribution (Sarrazin et al., 1999; Le Bris et al., 2005; Podowski et al., 2010), but in all studies, the examined environmental parameters could explain only a small percentage of the differences among the various community patches. Other factors such as species interactions (Micheli et al., 2002) and colonization history (Le Bris et al., 2006) are also known to contribute to the communities' composition. For instance, the early colonizers often alter the physicochemical parameters of their surrounding environment and facilitate (or inhibit) colonization by other species (Mullineaux et al., 2003; Pradillon et al., 2009; Govenar, 2010). In the Indian HTVs, neither the small-scale abiotic environments nor the species interactions have been sufficiently characterized for determining their roles in the composition and distribution of species assemblages. Furthermore, models of niche partition from better-studied vent 
Inter-oceans Intra-oceans/Inter-ridge Intra-ridge/Inter-site
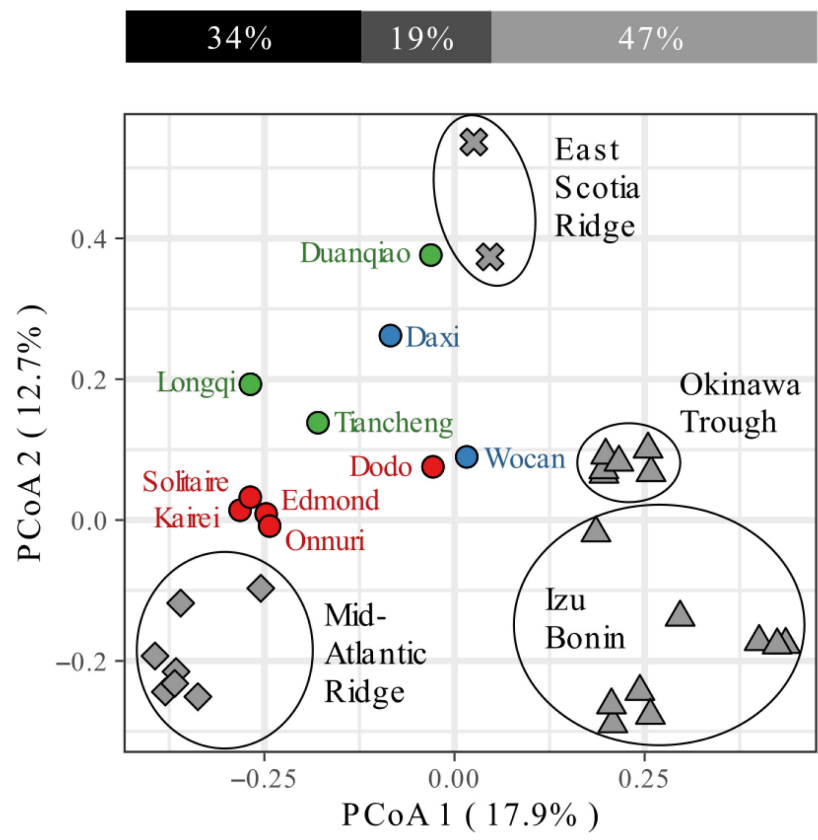

Ocean:

Indian Ocean

$\square \quad$ Antarctic Ocean

$\mho$ Atlantic Ocean

$\triangle$ Pacific Ocean

Indian ridge:

○ CIR

○ CR

SWIR

FIGURE 2 | Partition of the variance in community composition (genus level) across hydrothermal vents in the Indian, Antarctic, Atlantic, and West Pacific oceans. The Principal Coordinate Analysis (PcoA) plot is based on the Jaccard distance between vent sites. The presence/absence of taxa was compiled from Wang et al. (2021); Nakajima et al. (2014), Sun et al. (2020), and Kim et al. (2020), building upon Copley et al. (2016) and is provided as Supplementary Material with additional $\beta$-diversity indices. All hierarchical levels (inter-ocean and inter-ridge) significantly contribute to the observed differences in community composition at the genus level (db-RDA $p$-value $=0.001$ ). ANOSIM analyses also support the ocean- and ridge-level groupings of vent communities $($ significance $=1 \mathrm{e}-04)$ with dissimilarities across mid-ocean ridges higher than across oceans (ANOSIM statistic $R=0.8$ and 0.59 , respectively). Within the Indian Ocean, ridge-level groups are statistically significant but less supported (ANOSIM significance $=0.0245$ ). Note that the species lists for CR vents are likely incomplete due to lower sampling effort.

fields cannot be directly applied to the Indian HTV because of the different chemical composition of their hydrothermal fluids (Kumagai et al., 2008; Wang et al., 2017) and because of the different species composition of their communities.

\section{Local-Scale Temporal Succession}

Macrofaunal communities at vents typically shift overtime in response to changes in hydrothermal output and biologically driven changes in environmental conditions. Analysis on the temporal community succession in the Indian Ocean HTVs has always been hindered by the lack of continuous observations and a small number of available reports. Such succession was observed at Longqi with varying degrees throughout the site (Zhou et al., 2018). After revisiting the same black smoker at Longqi, Zhou et al. (2018) found that in the span of 3 years, its venting output had diminished considerably while at the same time, the diversity of its macrofaunal communities had increased and "peripheral" species commonly found at other diffuse vents (e.g., Neolepas sp., B. marisindicus) had been recruited. In contrast, the authors noticed the community assemblages in the areas of the vent field with more diffuse flow had been highly stable. In these environments, most taxa found in 2011 were found again in 2014/2015, and the pattern of their spatial zonation was conserved. This intra-site variation in community stability was also observed on the Juan de Fuca Ridge, where the communities living on the active sulfide chimneys shifted rapidly on the order of months to a few years (Sarrazin et al., 1997), whereas the communities on basalts away from the sulfide edifices were estimated to be at least 30 years old (Urcuyo et al., 2007).

\section{Food Webs}

Few studies have investigated food web structures of macrofaunal communities in the Indian vents and reported that these communities possessed 2-4 trophic levels (Van Dover et al., 2001; Copley et al., 2016; Reid et al., 2020). These short trophic chains are typical of other vent communities [e.g., in the EPR (Gaudron et al., 2012; Reid et al., 2013), Juan de Fuca Ridge (Bergquist et al., 2007; Sweetman et al., 2013; Lelièvre et al., 2017), and MAR (Vereshchaka et al., 2000)].

The dominant macrofaunal species are typically symbiotic primary consumers. Unique stable isotope signatures and additional evidence from in situ hybridization and hologenomic analyses revealed that these dominant taxa rely heavily or exclusively on chemosymbionts for food, including C. squamiferum (Van Dover, 2002; Goffredi et al., 2004; Nakagawa et al., 2014; Chen et al., 2015b; Reid et al., 2020), Gigantopelta aegis (Copley et al., 2016; Lan et al., 2021), Alviniconcha marissindica (Miyazaki et al., 2020; Yang Y. et al., 2020), R. kairei (Zbinden et al., 2008; Petersen et al., 2010; 
Guri et al., 2012; Jiang et al., 2020), and B. marisindicus (Yamanaka et al., 2003; McKiness and Cavanaugh, 2005; Copley et al., 2016). With the exception of C. squamiferum and G. aegis, symbiosis was known for congeneric species of these taxa in other oceans (Belkin et al., 1986; Stein et al., 1988; Endow and Ohta, 1989; Nelson et al., 1995; Rieley et al., 1999; Won et al., 2003). Carbon and nitrogen stable isotope analyses suggest most of the other species are omnivorous, possibly feeding on bacterial mats, mucus biofilms, and/or animal tissues (Van Dover, 2002). In the CIR, the highest trophic levels are composed of the polynoids Branchinotogluma, nemertean worms, and anemones for which direct predation on shrimp was captured on video surveys (Van Dover, 2002).

This first sketch of the food webs of the Indian vent ecosystems appears to reflect a resilient trophic structure with a few dominant symbiotic species and many opportunistic primary or secondary consumers. However, trophic ecology for most of the Indian vent ecosystems remains unknown. First, the primary producers have not sufficiently been identified to provide an accurate estimation of the diversity of food sources. Next, observations on animal behavior are too insufficient to infer trophic interactions with confidence. Third, the communities at the meio- and microscale, where many trophic interactions are expected to happen (Schmid-Araya and Schmid, 2000; Zekely et al., 2006; Nomaki et al., 2008, 2019; Ptatscheck et al., 2020), remain virtually undescribed. Only one study characterizing the Indian vent meiofaunal communities has been published to date (Kang and Kim, 2021). Last but not least, how these structures vary in time and space is unclear. Furthermore, ontogenic shifts in diet were observed in vent arthropods both in the Indian Ocean and elsewhere (Van Dover, 2002; Methou et al., 2020), and the microbial diet of several species varies across sites (Reid et al., 2020; Ma and Wang, 2021). However, the implications of these changes in food source on the ecology and adaptability of vent animals are still obscure.

\section{Active vs. Inactive Sites}

Mining plans for polymetallic sulfides suggest that activities be focused on inactive chimneys and vent fields to avoid technical issues posed by hot and reduced hydrothermal fluids, and to mitigate the impact on vent fauna; inactive sites do not have the lush vent communities typically found at active sites. Yet, the idea that inactive sites are of lesser or no biological interest has been challenged by the discovery of unique slow-growing communities in the West Pacific (Boschen et al., 2015; Du Preez and Fisher, 2018). A call has been made for a better understanding of the ecosystem functions and services of hydrothermally inactive sites (Van Dover et al., 2020). Active and inactive chimneys represent vastly different ecosystems, and inactive chimneys are neither lifeless nor akin to other diffuse flow ecosystems as initially hypothesized (Van Dover, 2019). At the Longqi site, the biodiversity in the diffuse-flow environments was lost at the inactive chimneys, which were occupied exclusively by the polychaete Amphisamytha sp. (Zhou et al., 2018). On the CIR, Gerdes et al. (2019) characterized five discrete types of faunal assemblages across the active and inactive vent fields of Edmond and Gauss, respectively, and found that assemblages in inactive vents were distinct from those of active vents, those at the periphery of active vents, and typical non-vent assemblages. The effect of substrate composition on the community structure was significant but could explain only a small percentage of the variation (12.5\%) observed across the different communities. Another study that surveyed the microbial diversity on active and inactive vent chimneys at the Kairei and Pelagia vent fields revealed the inactive chimneys are home to rare and unique microbes (Han et al., 2018). Overall, these studies support the idea that inactive chimneys and inactive vent fields in the Indian Ocean hold important biological resources and stress that they should be better studied to assess their role in the ecosystem function of HTVs (Van Dover et al., 2020).

\section{Community Differences Across Vent Fields}

An important first step to characterize the ecological niche of vent species in the Indian Ocean is to assess the natural variability of HTV communities. Corroborating the variation in community composition with environmental parameters can provide important information on the physicochemical factors that affect species distribution and thus their resilience. On a larger scale, differences in community structure are also a first line of evidence for biological barriers to connectivity.

The vent field ecosystems on Carlsberg Ridge (CR) and the Southeast Indian Ridge (SEIR) have not been sufficiently investigated to assess intra-ridge variation but even if sampling was sparse, multiple HTVs have been characterized within each of the CIR and SWIR (Figures 3, 4). On each of the SWIR and CIR, the community composition of the macrofauna and microbiota differs across vent sites and these variations correlate with distance. $R$. kairei shrimps, for instance, form dense swarms at Edmond and Kairei (near the Rodrigues Triple Junction) but are more sparse in the northernmost vents of Dodo and Solitaire (Beedessee et al., 2013). Whether the

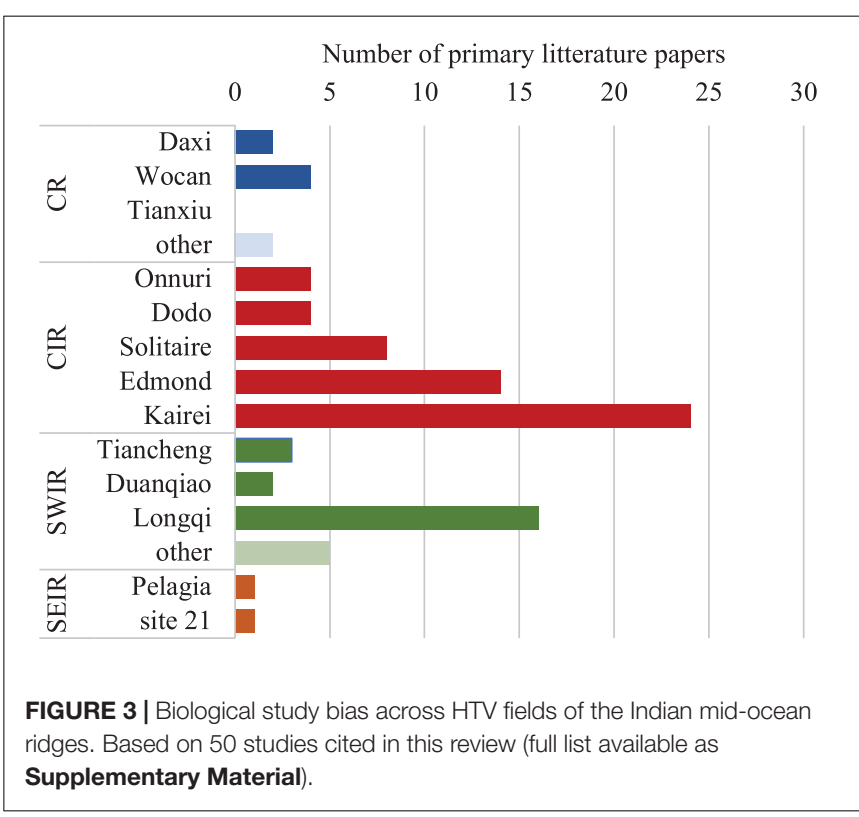




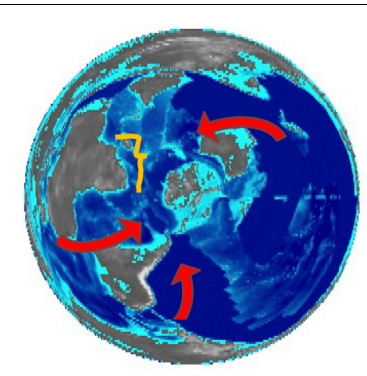

50 Mya

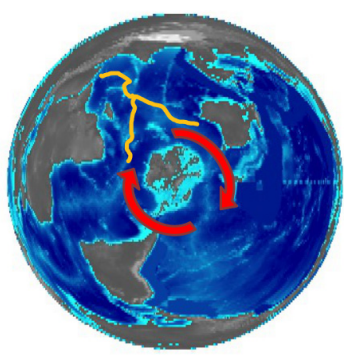

10 Mya
FIGURE 4 | Possible migration routes for vent species into the Indian Ocean Paleo-digital elevation models from Scotese and Wright (2018) viewed from the South Pole. The Indian spreading ridges are sketched in yellow.

underlying attributes of the shifts in community structure are local differences in environmental conditions or patterns of population connectivity is still unclear. For example, the stalked barnacle (Watanabe et al., 2018) possesses distinct morphotypes along the CIR, but whether these morphological variations are the results of phenotypic plasticity or genetic differentiation between populations is unknown. The stalked barnacle did not appear to be genetically different across vent fields, but their phylogenetic relationship was assessed only by using the mitochondrial COI gene, which is not good enough to discriminate closely related populations (Paz-Vinas et al., 2021).

The strongest contrasts in community composition were detected across the mid-ocean ridges. The first vent macrofauna described from CR was characterized by a high abundance of the polychetes Hesiolyra heteropoda and Paralvinella mira (Han et al., 2021) and dense swarms of $R$. kairei. CR communities showed the highest similarity to the CIR (Wang et al., 2021) but did not include other common species found at the CIR and SWIR, such as C. squamiferum, A. marisindica, and B. marisindicus. Disparate species are also found across the CIR and SWIR. Taxa present only at the SWIR include Gigantopelta aegis, Ophryotrocha n. sp. "F-038/1b," Phymorhynchus n. sp. "SWIR," and Lepetodrilus n. sp. "SWIR" (Copley et al., 2016), whereas Alviniconcha marisindica is a common species at both the CIR and CR but absent at the SWIR (Copley et al., 2016; Zhou et al., 2018). Across the CIR and SWIR, the abundance of $R$. kairei is much lower (or even found as solitaire individuals) at the SWIR than at the CIR (Copley et al., 2016; Zhou et al., 2018). Such strong contrasts in community composition were also observed across the disjunct spreading ridges of the eastern Pacific (Tunnicliffe, 1988; Van Dover et al., 1990), indicating that the topological discontinuities along the Indian spreading ridges likely act as strong barriers to dispersal for many species.

\section{CONNECTIVITY}

\section{Indian Mid-Ocean Ridges Communities as Melting Pots of Atlantic and Pacific Vent Species}

One long-held hypothesis is that the Indian ridges act as a corridor of population connectivity between the Atlantic and Western Pacific vents (German et al., 1998). This idea was brought up by early surveys of global vent biodiversity on the basis of the presence/absence of vent macrofauna, which classified the Indian vents into a distinct biogeographic province with strong connection to both the Atlantic and West Pacific provinces (Ramirez-Llodra et al., 2007; Moalic et al., 2012; Figure 2). Many studies investigating the biogeography of macrofaunal taxa at the species level also highlighted the evolutionary connection between the Atlantic, Pacific, and Indian oceans (Hashimoto et al., 2001; McKiness and Cavanaugh, 2005; Ramirez-Llodra et al., 2007; Miyazaki et al., 2010; Rogers et al., 2012; Borda et al., 2013; Roterman et al., 2013; Breusing et al., 2015, 2020; Chen et al., 2015b; Johnson et al., 2015; Copley et al., 2016; Watanabe et al., 2018; Zhou et al., 2018; Lee et al., 2019; Jang et al., 2020; Han et al., 2021). However, an important detail to recognize is that these biogeographical inferences are at a high taxonomic level (i.e., comparing closely related species) rather than the population level and thus may be indicative of past migration but may not necessarily be the current existing connection. For this reason, a potentially safer approach is to describe the Indian Ocean HTVs as a mosaic of colonizers from the Atlantic and Western Pacific oceans rather than as a corridor between them until more solid evidence on corridor theory becomes available.

Recent studies have shed new light into the dispersal route of some of the Indian vent taxa (Figure 4). One possible dispersal route was through the deep water passage between the Eurasian and Australian plates present in the Eocene (50-30 Mya). Vent endemics, which are most closely related to congeners from the West Pacific Ocean (e.g., Alviniconcha, Paralvinella), tend to be prevalent in the northernmost Indian hydrothermal fields (McKiness and Cavanaugh, 2005; Miyazaki et al., 2010; Borda et al., 2013; Breusing et al., 2015, 2020; Johnson et al., 2015; Zhou et al., 2018; Lee et al., 2019; Jang et al., 2020; Han et al., 2021). Molecular clocks calibrated on fossil records corroborate this hypothesis for Alviniconcha (Breusing et al., 2020). A. marisindica and $A$. boucheti appear to have speciated about 38 Mya (Breusing et al., 2020). HTVs generated from hot-spot volcanism during the northward migration of the Indian plate during the Eocene possibly served as a stepping stones for this species and others to reach the nascent mid-ocean spreading ridge that includes current CR and CIR. Species that are able to colonize other chemosynthetic environments such as cold seeps may have been able to use a variety of migration routes and maintain high connectivity across the Pacific and Indian oceans for extended periods (Breusing et al., 2015).

A more recent colonization event appears to have brought species from the East Pacific and Atlantic oceans into the SWIR through the Southern Ocean superconvergence. With the increasing intensity of the Antarctic Circumpolar Current during the middle Miocene ( $\sim 13.0 \mathrm{Mya})$, species in the Southern Ocean may have been isolated from the MAR and EPR and pushed eastward. This dispersal route is supported by fossil records and phylogeography of several taxa from SWIR that are closely related to those from East Scotia Ridge in the southern Atlantic Ocean, including Kiwa spp. (Roterman et al., 2013), G. aegis (Chen et al., 2015b), the polychaetes Polinoidae and Hesiolyra cf. bergi (Copley et al., 2016; Wang et al., 2020), and Neolepas marisindica 
(Rogers et al., 2012; Watanabe et al., 2018). Interestingly, these taxa are most abundant at the easternmost SWIR sites (Longqi and Duanqiao) (Zhou et al., 2018), suggesting a higher historical connectivity within ridges along the Southern Ocean.

\section{Current Patterns of Connectivity Within and Across Indian Mid-Ocean Ridges}

Modern vent species have multiple interconnected subpopulations (Vrijenhoek, 1997). The population structure and migrant flux of each species are closely linked to the persistence of these metapopulations and are therefore of great interest for conservation. When vent populations are structured according to the stepping stone model (Kimura and Weiss, 1964), they are well connected to their close neighbors, leading to a pattern of genetic variation with distance. In this scenario, the destruction of a habitat can lead to interruptions in the gene flow and isolate populations, thus making them more vulnerable to extinction. However, under the island model of population structure, species have high dispersal capabilities and are not affected by distance, but differences in habitat quality may result in patches of "source" populations that produce many dispersing migrants and "sink" populations sustained by constant import of new recruits (Vrijenhoek, 1997). In this scenario, extinction of source populations would negatively impact the sink sites.

The current patterns of connectivity of five macrofaunal taxa (B. marisindicus, A. marisindica, C. squamiferum, A. rodriguezensis, and $R$. kairei) for the Indian Ocean HTVs were evaluated using population genetics. High connectivity among the vent fields within the CIR was found (Nakamura et al., 2012; Beedessee et al., 2013; Chen et al., 2015a; Watanabe et al., 2018; Breusing et al., 2020) although these studies could provide only a coarse resolution of the population structures because few vent fields were surveyed (a maximum of four), a relatively small number of individuals (less than 50) were sampled within each site, and only one or few conserved genetic markers were used. Nevertheless, the estimated gene flow appeared to be from the southern (Kairei and Edmond) to northern sites, (Solitaire), suggesting that the southern vent fields serve as sources of dispersing migrants (Beedessee et al., 2013; Chen et al., 2015a).

Across the CIR and SWIR, a striking pattern of genetic isolation was observed (Chen et al., 2015a; Sun et al., 2020) and the topography of the Rodrigues Triple Junction was hypothesized as a strong dispersal barrier between the spreading ridges (Chen et al., 2015a). However, populations sampled from a venting site on the SWIR near the triple junction displayed strong gene flow with the CIR vents located at the triple junction, supporting a stepping stone model for larval dispersal and also indicating that transform faults on the SWIR itself are the strongest barriers to connectivity between SWIR and CIR (Sun et al., 2020).

\section{Variation Across Species}

Vent connectivity of macrofaunal species is a process influenced by the interactions of oceanic currents and larval biology (Adams et al., 2012). The dispersal of larvae is strongly affected by their vertical position in the water column because hydrothermal activity and ridge topography lead to a layering of currents with contrasting speed and direction. For instance, the Endeavor segment of the Juan de Fuca Ridge is characterized by deep valleys that trap buoyant hydrothermal water and the southward outflow of this water mass forces an northward inflow of near-bottom cold water (Thomson et al., 2003). Hence, swimming larvae may be able to reach shallower, stronger currents and thus disperse further, while the dispersal of the others will be dictated by their buoyancy (Adams et al., 2012; Yahagi et al., 2017).

In the Indian Ocean, different HTV taxonomic groups with different larval characteristics displayed different dispersal patterns on the basis of genetic data. At the CIR, some crustacean populations appear to reproduce periodically as multimodal distributions of sizes (an indication of multiple animal cohorts) were observed for $A$. rodriguezensis and $R$. kairei at some sites (Beedessee et al., 2013). Furthermore, A. rodriguezensis, unlike other species such as the scaly-foot snail or Alvinichoncha sp., disperses preferentially in a southward direction and its source population seems to be in the Solitaire vent field rather than Edmond or Kairei (Beedessee et al., 2013). It is possible that the crab larvae are active swimmers and use currents in the upper water column to disperse further and across topological discontinuities. On the MAR, the population structure of the shrimp Rimicaris exoculata also suggests widespread connectivity (Teixeira et al., 2012). In contrast, the genetic structure of the scaly-foot snail populations indicates that this species can be widely discovered across the whole Indian Ocean Ridge, suggesting a stronger dispersal ability. However, its dispersal may be strongly affected by topographical barriers such as transform faults. This hypothesis is supported by the fact that the scaly-foot snail has negatively buoyant eggs (Beedessee et al., 2013; Sun et al., 2020). Moving forward, more information on the reproductive and larval biology and life history of vent specie coupled with better models of deep-sea flow dynamics (Giangrande et al., 2017) is crucial to assess the decadal-scale patterns of population connectivity of vent species in the Indian Ocean.

\section{PERSPECTIVE: KNOWLEDGE GAPS TO PRIORITIZE FOR ASSESSING THE RESILIENCE OF INDIAN VENT COMMUNITIES}

Since the first discovery of a biologically active HTV in the West Indian Ocean in 2000, 13 biologically active vent fields have been discovered and a few more have been inferred through the detection of hydrothermal plumes. Among the four active spreading ridges of the Indian Ocean, CR and the SEIR have just been explored recently (Figure 3 ). In the recent years, the ISA has granted exploration permits to governmental and semiprivate entities for exploring HTV fields in the Indian Ocean. Contractors are requested to collect and submit environmental and biodiversity baseline information to the ISA (International Seabed Authority, 2021), which encourages more field surveys to be conducted in the Indian Ocean HTVs and will help fill the gaps in our understanding of connectivity and biodiversity of the areas of concerns. On the basis of all the publicly available information, 
we identified several knowledge gaps critical for assessing the resilience of Indian HTV biological communities.

\section{What Is the Vent Biodiversity at Meso- and Microscales?}

Compared with macrofaunal communities, much less focus has been given to meiofauna and microbiotas even though they are recognized as key players for ecosystem function (Finlay et al., 1997; Schratzberger and Ingels, 2018). Only a handful of studies have examined the biodiversity of Indian HTV microorganisms in various microhabitats. These genetic surveys revealed that microbial vent communities are distinct from those of the Atlantic or Pacific vents (Ding et al., 2017; Li et al., 2020; Yang Z. et al., 2020), are highly specialized to their local environment, and may hold great biological novelty. In the SWIR, the microbial community structures on active chimneys (Ding et al., 2017) and vent sediments (Xu et al., 2018; Yang Z. et al., 2020) vary within a single vent field or a single chimney structure according to the temperature and chemical composition of the substrates. On the CIR, active and inactive vent chimneys at the Kairei and Pelagia HTV fields are home to distinct microbes, many of which are rare and expected to hold unique biological innovations (Han et al., 2018; Van Dover, 2019). Metagenome barcoding and eDNA appear to be useful proxies for further assessing biodiversity at the meio- and microscales. Meta-transcriptomic data at various size fractions would provide additional information about cross-scale biological interactions, which are key to assessing ecosystem function.

\section{What Drives the Variance in Community Composition?}

Vents on the Indian mid-ocean ridges are similar to other vent systems in that their communities are characterized by high endemicity and spatial variance of their composition. To date, only a small fraction of the variation in community composition can somewhat be explained by abiotic physio-chemical factors (Sarrazin et al., 1999, 2015), but the physical environment has not been well studied at small scales (e.g., within the range of the faunal succession). The influence of life history traits (reproduction, larval development, larval dispersal, settlement process, and so on) on species dispersal, gene flows, population genetics, and evolutionary process remains unknown for most taxa (see more discussion below). Furthermore, the impact of temporal and spatial population dynamics of individual vent species and the role of species interactions (competition, mutualism, etc.) in structuring vent macrofaunal community and biogeographical patterns have hardly been tested in the Indian Ocean. Biological adaptation to environmental variables and the resilience and constraints of vent communities in response to natural environmental disturbances are also fundamental information for a better understanding of what drives the variance in community structures of the vent ecosystems. With the rapid development of deep-sea capacity, time series assessment by autonomous underwater observatories will be able to collect biological and environmental data at fine scales in the near future.

\section{How Diverse and Variable Are Community Functional Traits?}

The biological characteristics of species such as size, mobility, trophic mode, and body structure robustness are more ecologically informative than taxonomic rank alone (Faith, 2015; Gross et al., 2017; Biggs et al., 2020; de Bello et al., 2021). Thus, functional traits approaches are valuable to assess the resilience and recoverability of vent communities to various natural or anthropogenic disturbances. For instance, Boschen-Rose et al. (2021) used trait-based analyses to estimate the sensitivity of macrofaunal assemblages from the Kermadec volcanic arc to different types of mining impacts (such as sediment plume and seafloor disturbance by mining equipment) and produced local maps of vulnerable communities. Dykman et al. (2021) highlighted the need for trait-based impact assessments by showing that communities' functional diversity (a proxy for ecosystem stability and resilience) recovered more slowly than species diversity following an eruption in the EPR.

Such a trait-based perspective should be applied in the Indian Ocean. In fact, the current global database for functional diversity at vents (Chapman et al., 2019) already includes a fair number of taxa from the Indian Ocean HTVs. Still, to gain important insights into the ecosystem functions and resilience of Indian vents, the functional trait repertoire needs to be substantially expanded to represent a comprehensive collection of Indian vent animals and include better estimates of the variability associated with each of their trait. Functional traits related to species morphologic or behavioral phenotypes are context dependent and their variation can affect our predictions of ecosystem function (Cassidy et al., 2020). Hence, more research needs to be conducted to gather baseline information on the biology of Indian vent macrofauna, and communities need to be surveyed further to provide reliable estimates for the spatial and temporal variance of their traits.

\section{How Do the Life History Traits of Foundation Species Affect Connectivity and Community Structure?}

Vent connectivity has so far mostly been inferred from genetic data, which gives a rough picture of the general trend in gene flow over thousands of years (Lowe and Allendorf, 2010). This resolution may not be relevant for conservation purposes as impact assessments aim to determine the ability of an ecosystem to recover perturbation on much shorter time scales (i.e., years or decades). Hence, we need to know more about larval biology and colonization process especially for foundation species such as B. marisindicus. To assess demographic connectivity, we need more information of larval dispersal, colonization processes, and deep oceanic current patterns and variability. Better models of deep-sea currents would also allow us to make predictions as to the consequences of climate change. Dominant macrofaunal species of the Indian ridge HTVs rely on chemoautotrophic symbionts for their survival, and in many instances, these symbionts have a strong degree of specificity to their host and are acquired from the environment. Thus, these microbial species are keystone to the whole community. More focus should 
be placed on better understanding their biology, distribution, and connectivity.

\section{How Many HTV Fields Are in the Indian Mid-Ocean Ridges?}

Last but not least, one obvious gap to our understanding of vent population connectivity in the Indian Ocean spans from the fact that we do not know how many HTV fields are present, and for the vent fields that we do know (including both active and inactive fields), we have yet to acquire fine-resolution topographic and bathymetric maps. Given this sporadic sampling and the lack of sufficient information on near-bottom current, near-field, and far-field flow dynamic, estimating regional connectivity between vents is highly challenging. The seemingly high gene flow observed for vent species across long distances and topographic discontinuities remains highly intriguing. One likely explanation is the presence of smaller and more diffuse HTV in between the known vent fields, which are predicted by geological modeling (Hashimoto et al., 2001; Beaulieu et al., 2015; Baker et al., 2016) but have yet to be discovered. Large-scale surveys of the seafloor enabled through additional ISA mineral exploration contracts could help fill these gaps if the mapping data were made publicly available.

\section{AUTHOR CONTRIBUTIONS}

P-YQ conceptualized the project. MP prepared the initial draft and figures. JS and QX provided inputs to the initial manuscript. All the authors revised the manuscript.

\section{FUNDING}

This study was supported by the China Ocean Mineral Resource Research and Development Association (DY135E2-1-03), the Guangdong Major Project of Basic and

\section{REFERENCES}

Adams, D., Arellano, S., and Govenar, B. (2012). Larval dispersal: vent life in the water column. oceanog 25, 256-268. doi: 10.5670/oceanog.2012.24

Bachraty, C., Legendre, P., and Desbruyères, D. (2009). Biogeographic relationships among deep-sea hydrothermal vent faunas at global scale. Deep Sea Res. Part I Oceanogr. Res. Papers 56, 1371-1378. doi: 10.1016/j.dsr.2009.01.009

Baker, E. T., Chen, Y. J., and Phipps Morgan, J. (1996). The relationship between near-axis hydrothermal cooling and the spreading rate of mid-ocean ridges. Earth Planet. Sci. Lett. 142, 137-145. doi: 10.1016/0012-821X(96)00097-0

Baker, E. T., Edmonds, H. N., Michael, P. J., Bach, W., Dick, H. J. B., Snow, J. E., et al. (2004). Hydrothermal venting in magma deserts: The ultraslowspreading Gakkel and Southwest Indian Ridges. Geochem. Geophys. Geosyst. 5:2004GC000712. doi: 10.1029/2004GC000712

Baker, E. T., Resing, J. A., Haymon, R. M., Tunnicliffe, V., Lavelle, J. W., Martinez, F., et al. (2016). How many vent fields? New estimates of vent field populations on ocean ridges from precise mapping of hydrothermal discharge locations. Earth Planet. Sci. Lett. 449, 186-196. doi: 10.1016/j.epsl.2016.05.031

Beaulieu, S. E. (2015). InterRidge global database of active submarine hydrothermal vent fields: prepared for InterRidge, Version 3.4. Available online at: http://ventsdata.interridge.org (accessed March 6, 2018)
Applied Basic Research (2019B030302004-04), the Southern Marine Science and Engineering Guangdong Laboratory (Guangzhou) (GML2019ZD0409), and the Hong Kong Branch of South Marine Science and Engineering Guangdong Laboratory (SMSEGL20Sc01). Additional support was provided to MP by the Quebec Centre for Biodiversity Science (QCBS) and the "Fonds Québécois de la Recherche sur la Nature et les Technologies" (FRQNT) international internship grant.

\section{ACKNOWLEDGMENTS}

In preparation for this review, the authors used relevant information from the "Data Report: compilation of scientific information on the HTV fields along the mid-ocean ridge in the west Indian Ocean," which was prepared by a group of Chinese marine scientists supported by China Ocean Mineral Resource Research and Development Association and distributed to all the participants of the "ISA workshop on marine science research in the Area: establishing collaborative platform to enhance biodiversity knowledge for environmental management in midocean ridge ecosystem focusing on the Indian Ocean," which was held online from December 15-17, 2020. In particular, the authors would like to thank Chengjun Sun, $\mathrm{Li} \mathrm{Li}$, and Lingyun $\mathrm{Qu}$ from the First Institute of Oceanography, Ministry of Natural Resource, and Yadong Zhou and Xiqiu Han from the Second Institute of Oceanography, Ministry of Natural Resource. who contributed to the preparation of that data report.

\section{SUPPLEMENTARY MATERIAL}

The Supplementary Material for this article can be found online at: https://www.frontiersin.org/articles/10.3389/fmars. 2021.744874/full\#supplementary-material

Beaulieu, S. E., Baker, E. T., and German, C. R. (2015). Where are the undiscovered hydrothermal vents on oceanic spreading ridges? Deep Sea Res. Part II Top. Stud. Oceanogr. 121, 202-212. doi: 10.1016/j.dsr2.2015.05.001

Beedessee, G., Watanabe, H., Ogura, T., Nemoto, S., Yahagi, T., Nakagawa, S., et al. (2013). High connectivity of animal populations in deep-sea hydrothermal vent fields in the Central Indian Ridge relevant to its geological setting. PLoS One 8:e81570. doi: 10.1371/journal.pone.0081570

Belkin, S., Nelson, D. C., and Jannasch, H. W. (1986). Symbiotic assimilation of $\mathrm{CO}_{2}$ in two hydrothermal vent animals, the mussel Bathymodiolus thermophilus and the tube worm Riftia pachyptila. Biol. Bull. 170, 110-121. doi: 10.2307/ 1541384

Bell, J. B., Woulds, C., Oevelen, D., and van. (2017). Hydrothermal activity, functional diversity and chemoautotrophy are major drivers of seafloor carbon cycling. Sci. Rep. 7:12025. doi: 10.1038/s41598-017-12291-w

Bergquist, D., Eckner, J., Urcuyo, I., Cordes, E., Hourdez, S., Macko, S., et al. (2007). Using stable isotopes and quantitative community characteristics to determine a local hydrothermal vent food web. Mar. Ecol. Prog. Ser. 330, 49-65. doi: $10.3354 /$ meps330049

Biggs, C. R., Yeager, L. A., Bolser, D. G., Bonsell, C., Dichiera, A. M., Hou, Z., et al. (2020). Does functional redundancy affect ecological stability and resilience? A review and meta-analysis. Ecosphere 11:e03184. doi: 10.1002/ecs2.3184 
Borda, E., Kudenov, J. D., Chevaldonné, P., Blake, J. A., Desbruyères, D., Fabri, M.C., et al. (2013). Cryptic species of Archinome (Annelida: Amphinomida) from vents and seeps. Proce. R. Soc. B Biol. Sci. 280:20131876. doi: 10.1098/rspb.2013. 1876

Boschen, R. E., Rowden, A. A., Clark, M. R., Barton, S. J., Pallentin, A., and Gardner, J. P. A. (2015). Megabenthic assemblage structure on three New Zealand seamounts: implications for seafloor massive sulfide mining. Mar. Ecol. Prog. Ser. 523, 1-14. doi: 10.3354/meps11239

Boschen-Rose, R. E., Clark, M. R., Rowden, A. A., and Gardner, J. P. A. (2021). Assessing the ecological risk to deep-sea megafaunal assemblages from seafloor massive sulfide mining using a functional traits sensitivity approach. Ocean Coastal Manage. 210:105656. doi: 10.1016/j.ocecoaman.2021.105656

Breusing, C., Johnson, S. B., Tunnicliffe, V., and Vrijenhoek, R. C. (2015). Population structure and connectivity in Indo-Pacific deep-sea mussels of the Bathymodiolus septemdierum complex. Conserv. Genet. 16, 1415-1430. doi: 10.1007/s10592-015-0750-0

Breusing, C., Johnson, S. B., Tunnicliffe, V., Clague, D. A., Vrijenhoek, R. C., and Beinart, R. A. (2020). Allopatric and sympatric drivers of speciation in Alviniconcha hydrothermal vent snails. Mol. Biol. Evolut. 37, 3469-3484. doi: 10.1093/molbev/msaa177

Cassidy, C., Grange, L. J., Garcia, C., Bolam, S. G., and Godbold, J. A. (2020). Species interactions and environmental context affect intraspecific behavioural trait variation and ecosystem function. Proc. R. Soc. B Biol. Sci. 287:20192143. doi: 10.1098/rspb.2019. 2143

Chapman, A. S. A., Beaulieu, S. E., Colaço, A., Gebruk, A. V., Hilario, A., Kihara, T. C., et al. (2019). sFDvent: A global trait database for deep-sea hydrothermalvent fauna. Glob. Ecol. Biogeogr. 28, 1538-1551. doi: 10.1111/geb.12975

Chen, C., Linse, K., Roterman, C. N., Copley, J. T., and Rogers, A. D. (2015b), A new genus of large hydrothermal vent-endemic gastropod (Neomphalina: Peltospiridae). Zool. J. Linnean Soc. 175, 319-335. doi: 10.1111/zoj.12279

Chen, C., Copley, J. T., Linse, K., and Rogers, A. D. (2015a). Low connectivity between 'scaly-foot gastropod' (Mollusca: Peltospiridae) populations at hydrothermal vents on the Southwest Indian Ridge and the Central Indian Ridge. Org. Divers. Evol. 15, 663-670. doi: 10.1007/s13127-015-0224-8

Connelly, D. P., German, C. R., Asada, M., Okino, K., Egorov, A., Naganuma, T., et al. (2007). Hydrothermal activity on the ultra-slow spreading southern Knipovich Ridge. Geochem. Geophys. Geosyst. 8:2007GC001652. doi: 10.1029/ 2007GC001652

Copley, J. T., Marsh, L., Glover, A. G., Hühnerbach, V., Nye, V. E., Reid, W. D. K., et al. (2016). Ecology and biogeography of megafauna and macrofauna at the first known deep-sea hydrothermal vents on the ultraslow-spreading Southwest Indian Ridge. Sci. Rep. 6:39158. doi: 10.1038/srep39158

de Bello, F., Lavorel, S., Hallett, L. M., Valencia, E., Garnier, E., Roscher, C., et al. (2021). Functional trait effects on ecosystem stability: assembling the jigsaw puzzle. Trends Ecol. Evolut. 2021:001. doi: 10.1016/j.tree.2021.05.001

Dick, H. J. B., Lin, J., and Schouten, H. (2003). An ultraslow-spreading class of ocean ridge. Nature 426, 405-412. doi: 10.1038/nature02128

Ding, J., Zhang, Y., Wang, H., Jian, H., Leng, H., and Xiao, X. (2017). Microbial community structure of deep-sea hydrothermal vents on the ultraslow spreading Southwest Indian Ridge. Front. Microbiol. 8:01012. doi: 10.3389/ fmicb.2017.01012

Dover, C. L. V., and Doerries, M. B. (2005). Community structure in mussel beds at Logatchev hydrothermal vents and a comparison of macrofaunal species richness on slow- and fast-spreading mid-ocean ridges. Mar. Ecol. 26, 110-120. doi: $10.1111 / j .1439-0485.2005 .00047 . x$

Du Preez, C., and Fisher, C. R. (2018). Long-term stability of back-arc basin hydrothermal vents. Front. Mar. Sci. 5:00054. doi: 10.3389/fmars.2018.00054

Dykman, L. N., Beaulieu, S. E., Mills, S. W., Solow, A. R., and Mullineaux, L. S. (2021). Functional traits provide new insight into recovery and succession at deep-sea hydrothermal vents. Ecology 2021:e03418. doi: 10.1002/ecy.3418

Edmonds, H. N., Michael, P. J., Baker, E. T., Connelly, D. P., Snow, J. E., Langmuir, C. H., et al. (2003). Discovery of abundant hydrothermal venting on the ultraslow-spreading Gakkel ridge in the Arctic Ocean. Nature 421, 252-256. doi: $10.1038 /$ nature 01351

Ellis, J. I., Clark, M. R., Rouse, H. L., and Lamarche, G. (2017). Environmental management frameworks for offshore mining: the New Zealand approach. Mar. Policy 84, 178-192. doi: 10.1016/j.marpol.2017.07.004
Endow, K., and Ohta, S. (1989). The symbiotic relationship between bacteria and a mesogastropod snail, Alviniconcha hessleri, collected from hydrothermal vents of the Mariana Back-Arc Basin. Bull. Jap. Soc. Microb. Ecol. 3, 73-82. doi: 10.1264/microbes1986.3.73

Faith, D. P. (2015). The unimodal relationship between species' functional traits and habitat gradients provides a family of indices supporting the conservation of functional trait diversity. Plant Ecol. 216, 725-740. doi: 10.1007/s11258-0150454-z

Finlay, B. J., Maberly, S. C., and Cooper, J. I. (1997). Microbial diversity and ecosystem function. Oikos 80, 209-213. doi: 10.2307/3546587

Fjeldsaå, J., and Lovett, J. C. (1997). Biodiversity and environmental stability. Biodivers. Conservat. 6, 315-323. doi: 10.1023/A:1018304522320

Gaudron, S. M., Lefebvre, S., Nunes Jorge, A., Gaill, F., and Pradillon, F. (2012). Spatial and temporal variations in food web structure from newly-opened habitat at hydrothermal vents. Mar. Environ. Res. 77, 129-140. doi: 10.1016/j. marenvres.2012.03.005

Gerdes, K. H., Martínez Arbizu, P., Schwentner, M., Freitag, R., SchwarzSchampera, U., Brandt, A., et al. (2019). Megabenthic assemblages at the southern Central Indian Ridge - Spatial segregation of inactive hydrothermal vents from active-, periphery- and non-vent sites. Mar. Environ. Res. 151:104776. doi: 10.1016/j.marenvres.2019.104776

German, C. R., and Parson, L. M. (1998). Distributions of hydrothermal activity along the Mid-Atlantic Ridge: interplay of magmatic and tectonic controls. Earth Planet. Sci. Lett. 160, 327-341. doi: 10.1016/S0012-821X(98)00093-4

German, C. R., Baker, E. T., Mevel, C., Tamaki, K., and the Fuji Science Team. (1998). Hydrothermal activity along the southwest Indian ridge. Nature 395, 490-493. doi: $10.1038 / 26730$

German, C. R., Petersen, S., and Hannington, M. D. (2016). Hydrothermal exploration of mid-ocean ridges: Where might the largest sulfide deposits be forming? Chem. Geol. 420, 114-126. doi: 10.1016/j.chemgeo.2015.11.006

Giangrande, A., Gambi, M. C., and Gravina, M. F. (2017). Paradigm shifts in community ecology: Open versus closed units, challenges and limits of connectivity studies. Mar. Ecol. 38:e12480. doi: 10.1111/maec.12480

Goffredi, S. K., Warén, A., Orphan, V. J., Dover, C. L. V., and Vrijenhoek, R. C. (2004). Novel forms of structural integration between microbes and a hydrothermal vent gastropod from the Indian Ocean. Appl. Environ. Microbiol. 70, 3082-3090. doi: 10.1128/AEM.70.5.3082-3090.2004

Gollner, S., Colaço, A., Gebruk, A., Halpin, P. N., Higgs, N., Menini, E., et al. (2021). Application of scientific criteria for identifying hydrothermal ecosystems in need of protection. Mar. Policy 132:104641. doi: 10.1016/j.marpol.2021.104641

Gollner, S., Kaiser, S., Menzel, L., Jones, D. O. B., Brown, A., Mestre, N. C., et al. (2017). Resilience of benthic deep-sea fauna to mining activities. Mar. Environ. Res. 129, 76-101. doi: 10.1016/j.marenvres.2017.04.010

Govenar, B. (2010). "Shaping vent and seep communities: Habitat provision and modification by foundation species," in The Vent and Seep Biota: Aspects from Microbes to Ecosystems Topics in Geobiology, ed. S. Kiel (Dordrecht: Springer Netherlands), 403-432. doi: 10.1007/978-90-481-9572-5_13

Gross, N., Bagousse-Pinguet, Y. L., Liancourt, P., Berdugo, M., Gotelli, N. J., and Maestre, F. T. (2017). Functional trait diversity maximizes ecosystem multifunctionality. Nat. Ecol. Evol. 1, 1-9. doi: 10.1038/s41559-017-0132

Guri, M., Durand, L., Cueff-Gauchard, V., Zbinden, M., Crassous, P., Shillito, B., et al. (2012). Acquisition of epibiotic bacteria along the life cycle of the hydrothermal shrimp Rimicaris exoculata. ISME J. 6, 597-609. doi: 10.1038/ ismej.2011.133

Han, Y., Gonnella, G., Adam, N., Schippers, A., Burkhardt, L., Kurtz, S., et al. (2018). Hydrothermal chimneys host habitat-specific microbial communities: analogues for studying the possible impact of mining seafloor massive sulfide deposits. Sci. Rep. 8:10386. doi: 10.1038/s41598-018-28613-5

Han, Y., Zhang, D., Wang, C., and Zhou, Y. (2021). Out of the Pacific: a new alvinellid worm (Annelida: Terebellida) from the northern Indian Ocean hydrothermal vents. Front. Mar. Sci. 8:669918. doi: 10.3389/fmars.2021.669918

Harms, N. C., Lahajnar, N., Gaye, B., Rixen, T., Schwarz-Schampera, U., and Emeis, K.-C. (2021). Sediment trap-derived particulate matter fluxes in the oligotrophic subtropical gyre of the South Indian Ocean. Deep Sea Res. Part II Top. Stud. Oceanogr. 2021:104924. doi: 10.1016/j.dsr2.2020.104924

Hashimoto, J., Ohta, S., Gamo, T., Chiba, H., Yamaguchi, T., Tsuchida, S., et al. (2001). First hydrothermal vent communities from the Indian Ocean discovered. Jzoo 18, 717-721. doi: 10.2108/zsj.18.717 
Hessler, R. R., Smithey, W. M., Boudrias, M. A., Keller, C. H., Lutz, R. A., and Childress, J. J. (1988). Temporal change in megafauna at the Rose Garden hydrothermal vent (Galapagos Rift; eastern tropical Pacific). Deep Sea Res. Part A Oceanogr. Res. Papers 35, 1681-1709. doi: 10.1016/0198-0149(88)90044-1

International Seabed Authority (2018). ISBA/24/A/4: Consideration, with a view to adoption, of the draft strategic plan of the International Seabed Authority for the period 2019-2023. Kingston: International Seabed Authority.

International Seabed Authority (2021). Minerals: Polymetallic Sulphides. Available online at: https://www.isa.org.jm/exploration-contracts/polymetallic-sulphides (accessed March 25, 2021)

Jang, S.-J., Ho, P.-T., Jun, S.-Y., Kim, D., and Won, Y.-J. (2020). A newly discovered Gigantidas bivalve mussel from the Onnuri Vent Field in the northern Central Indian Ridge. Deep Sea Res. Part I Oceanogr. Res. Papers 161:103299. doi: 10.1016/j.dsr.2020.103299

Jiang, L., Liu, X., Dong, C., Huang, Z., Cambon-Bonavita, M.-A., Alain, K., et al. (2020). "Candidatus Desulfobulbus rimicarensis," an uncultivated deltaproteobacterial epibiont from the deep-sea hydrothermal vent shrimp Rimicaris exoculata. Appl. Environ. Microbiol. 86, 2549-2519. doi: 10.1128/ AEM.02549-19

Johnson, S. B., Warén, A., Tunnicliffe, V., Dover, C. V., Wheat, C. G., Schultz, T. F., et al. (2015). Molecular taxonomy and naming of five cryptic species of Alviniconcha snails (Gastropoda: Abyssochrysoidea) from hydrothermal vents. Systemat. Biodivers. 13, 278-295. doi: 10.1080/14772000.2014.97 0673

Juniper, S. K., and Tunnicliffe, V. (1997). Crustal accretion and the hot vent ecosystem. Philosop. Transact. R. Soc. London A Mathemat. Phys. Engine. Sci. 355, 459-474. doi: 10.1098/rsta.1997.0017

Kang, T., and Kim, D. (2021). Meiofauna and nematode community composition in a hydrothermal vent and deep-sea sediments in the Central Indian Ridge. Mar. Pollut. Bull. 170:112616. doi: 10.1016/j.marpolbul.2021.112616

Kim, J., Son, S.-K., Kim, D., Pak, S.-J., Yu, O. H., Walker, S. L., et al. (2020). Discovery of active hydrothermal vent fields along the central Indian Ridge, 8-12 S. Geochem. Geophys. Geosyst. 21:e2020GC009058. doi: 10.1029/ 2020GC009058

Kimura, M., and Weiss, G. H. (1964). The stepping stone model of population structure and the decrease of genetic correlation with distance. Genetics 49 , 561-576.

Kinsey, J. C., and German, C. R. (2013). Sustained volcanically-hosted venting at ultraslow ridges: Piccard Hydrothermal Field, Mid-Cayman Rise. Earth Planet. Sci. Lett. 380, 162-168. doi: 10.1016/j.epsl.2013.08.001

Kumagai, H., Nakamura, K., Toki, T., Morishita, T., Okino, K., Ishibashi, J.-I., et al. (2008). Geological background of the Kairei and Edmond hydrothermal fields along the Central Indian Ridge: Implications of their vent fluids' distinct chemistry. Geofluids 8, 239-251. doi: 10.1111/j.1468-8123.2008.00223.x

Lan, Y., Sun, J., Chen, C., Sun, Y., Zhou, Y., Yang, Y., et al. (2021). Hologenome analysis reveals dual symbiosis in the deep-sea hydrothermal vent snail Gigantopelta aegis. Nat. Commun. 12:1165. doi: 10.1038/s41467-021-21450-7

Le Bris, N., Govenar, B., Le Gall, C., and Fisher, C. R. (2006). Variability of physicochemical conditions in $9^{\circ} 50^{\prime} \mathrm{N}$ EPR diffuse flow vent habitats. Mar. Chem. 98, 167-182. doi: 10.1016/j.marchem.2005.08.008

Le Bris, N., Zbinden, M., and Gaill, F. (2005). Processes controlling the physicochemical micro-environments associated with Pompeii worms. Deep Sea Res. Part I Oceanogr. Res. Pap. 52, 1071-1083. doi: 10.1016/j.dsr.2005.01.003

Lee, W.-K., Ju, S.-J., Hou, B. K., and Kim, S.-J. (2019). DNA barcoding for the hydrothermal vent crab Austinograea species (Crustacea: Bythograeidae) from the North Fiji Basin, Southwestern Pacific Ocean. Anim. Systemat. Evolut. Divers. 35, 30-32. doi: 10.5635/ASED.2019.35.1.004

Lelièvre, Y., Sarrazin, J., Marticorena, J., Schaal, G., Day, T., Legendre, P., et al. (2017). Biodiversity and trophic ecology of hydrothermal vent fauna associated with tubeworm assemblages on the Juan de Fuca Ridge. Biogeosci. Discuss 2017, 1-34. doi: 10.5194/bg-2017-411

Li, J., Yang, J., Sun, M., Su, L., Wang, H., Gao, J., et al. (2020). Distribution and succession of microbial communities along the dispersal pathway of hydrothermal plumes on the Southwest Indian Ridge. Front. Mar. Sci. 7:581381. doi: $10.3389 /$ fmars.2020.581381

Lowe, W. H., and Allendorf, F. W. (2010). What can genetics tell us about population connectivity? Mol. Ecol. 19, 3038-3051. doi: 10.1111/j.1365-294X. 2010.04688.x
Ma, L., and Wang, W.-X. (2021). Zinc source differentiation in hydrothermal vent mollusks: Insight from $\mathrm{Zn}$ isotope ratios. Sci. Total Environ. 773:145653. doi: 10.1016/j.scitotenv.2021.145653

McKiness, Z. P., and Cavanaugh, C. M. (2005). The ubiquitous mussel: Bathymodiolus aff. brevior symbiosis at the Central Indian Ridge hydrothermal vents. Mar. Ecol. Prog. Ser. 295, 183-190. doi: 10.3354/meps295183

Methou, P., Michel, L. N., Segonzac, M., Cambon-Bonavita, M.-A., and Pradillon, F. (2020). Integrative taxonomy revisits the ontogeny and trophic niches of Rimicaris vent shrimps. R. Soc. Open Sci. 7:200837. doi: 10.1098/rsos.200837

Micheli, F., Peterson, C. H., Mullineaux, L. S., Fisher, C. R., Mills, S. W., Sancho, G., et al. (2002). Predation structures communities at deep-sea hydrothermal vents. Ecol. Monogr. 72, 365-382.

Miyazaki, J., Ikuta, T., Watsuji, T., Abe, M., Yamamoto, M., Nakagawa, S., et al. (2020). Dual energy metabolism of the Campylobacterota endosymbiont in the chemosynthetic snail Alviniconcha marisindica. ISME J. 14, 1273-1289. doi: 10.1038/s41396-020-0605-7

Miyazaki, J.-I., Martins, L., de, O., Fujita, Y., Matsumoto, H., and Fujiwara, Y. (2010). Evolutionary process of deep-sea Bathymodiolus mussels. PLoS One 5:e10363. doi: 10.1371/journal.pone.0010363

Moalic, Y., Desbruyères, D., Duarte, C. M., Rozenfeld, A. F., Bachraty, C., and Arnaud-Haond, S. (2012). Biogeography revisited with network theory: retracing the history of hydrothermal vent communities. Systemat. Biol. 61, 127-127. doi: 10.1093/sysbio/syr088

Müller, R. D., Sdrolias, M., Gaina, C., and Roest, W. R. (2008). Age, spreading rates, and spreading asymmetry of the world's ocean crust. Geochem. Geophys. Geosyst. 9:2007GC001743. doi: 10.1029/2007GC001743

Mullineaux, L. S., Peterson, C. H., Micheli, F., and Mills, S. W. (2003). Successional mechanism varies along a gradient in hydrothermal fluid flux at deep-sea vents. Ecol. Monogr. 73, 523-542. doi: 10.1890/02-0674

Nakagawa, S., Shimamura, S., Takaki, Y., Suzuki, Y., Murakami, S., Watanabe, T., et al. (2014). Allying with armored snails: the complete genome of gammaproteobacterial endosymbiont. ISME J. 8, 40-51. doi: 10.1038/ismej. 2013.131

Nakajima, R., Yamakita, T., Watanabe, H., Fujikura, K., Tanaka, K., Yamamoto, H., et al. (2014). Species richness and community structure of benthic macrofauna and megafauna in the deep-sea chemosynthetic ecosystems around the Japanese archipelago: an attempt to identify priority areas for conservation. Divers. Distribut. 20, 1160-1172. doi: 10.1111/ddi.12204

Nakamura, K., Watanabe, H., Miyazaki, J., Takai, K., Kawagucci, S., Noguchi, T., et al. (2012). Discovery of new hydrothermal activity and chemosynthetic fauna on the Central Indian Ridge at $18^{\circ}-20^{\circ}$ S. PLoS One 7:e32965. doi: 10.1371/ journal.pone. 0032965

Nelson, D. C., Hagen, K. D., and Edwards, D. B. (1995). The gill symbiont of the hydrothermal vent mussel Bathymodiolus thermophilus is a psychrophilic, chemoautotrophic, sulfur bacterium. Mar. Biol. 121, 487-495. doi: 10.1007/ BF00349457

Nomaki, H., Ogawa, N. O., Ohkouchi, N., Suga, H., Toyofuku, T., Shimanaga, M., et al. (2008). Benthic foraminifera as trophic links between phytodetritus and benthic metazoans: carbon and nitrogen isotopic evidence. Mar. Ecol. Prog. Ser. 357, 153-164. doi: 10.3354/meps07309

Nomaki, H., Uejima, Y., Ogawa, N., Yamane, M., Watanabe, H., Senokuchi, R., et al. (2019). Nutritional sources of meio- and macrofauna at hydrothermal vents and adjacent areas: natural-abundance radiocarbon and stable isotope analyses. Mar. Ecol. Prog. Ser. 622, 49-65. doi: 10.3354/meps13053

Paz-Vinas, I., Jensen, E. L., Bertola, L. D., Breed, M. F., Hand, B. K., Hunter, M. E., et al. (2021). Macrogenetic studies must not ignore limitations of genetic markers and scale. Ecol. Lett. 2021:13732. doi: 10.1111/ele.13732

Petersen, J. M., Ramette, A., Lott, C., Cambon-Bonavita, M., Zbinden, M., and Dubilier, N. (2010). Dual symbiosis of the vent shrimp Rimicaris exoculata with filamentous gamma-and epsilonproteobacteria at four Mid-Atlantic Ridge hydrothermal vent fields. Environment. Microbiol. 12, 2204-2218. doi: 10.1111/ j.1462-2920.2009.02129.x

Podowski, E., Ma, S., Luther, G., Wardrop, D., and Fisher, C. (2010). Biotic and abiotic factors affecting distributions of megafauna in diffuse flow on andesite and basalt along the Eastern Lau Spreading Center, Tonga. Mar. Ecol. Prog. Ser. 418, 25-45. doi: 10.3354/meps08797

Pradillon, F., Zbinden, M., Le Bris, N., Hourdez, S., Barnay, A.-S., and Gaill, F. (2009). Development of assemblages associated with alvinellid colonies on the 
walls of high-temperature vents at the East Pacific Rise. Deep Sea Res. Part II Top. Stud. Oceanogr. 56, 1622-1631. doi: 10.1016/j.dsr2.2009.05.009

Ptatscheck, C., Brüchner-Hüttemann, H., Kreuzinger-Janik, B., Weber, S., and Traunspurger, W. (2020). Are meiofauna a standard meal for macroinvertebrates and juvenile fish? Hydrobiologia 847, 2755-2778. doi: 10.1007/s10750-020-04189-y

Ramirez-Llodra, E., Shank, T. M., and German, C. M. (2007). Biodiversity and biogeography of hydrothermal vent species: thirty years of discovery and investigations. Oceanography 20, 30-41. doi: 10.5670/oceanog.2007.78

Reed, D. C., Breier, J. A., Jiang, H., Anantharaman, K., Klausmeier, C. A., Toner, B. M., et al. (2015). Predicting the response of the deep-ocean microbiome to geochemical perturbations by hydrothermal vents. ISME J. 9, 1857-1869. doi: $10.1038 /$ ismej.2015.4

Reid, W. D. K., Sweeting, C. J., Wigham, B. D., Zwirglmaier, K., Hawkes, J. A., McGill, R. A. R., et al. (2013). Spatial differences in East Scotia Ridge hydrothermal vent food webs: Influences of chemistry, microbiology and predation on trophodynamics. PLoS One 8:e65553. doi: 10.1371/journal.pone. 0065553

Reid, W. D. K., Wigham, B. D., Marsh, L., Weston, J. N. J., Zhu, Y., and Copley, J. T. (2020). Trophodynamics at the Longqi hydrothermal vent field and comparison with the East Scotia and Central Indian Ridges. Mar. Biol. 167:141. doi: 10.1007/ s00227-020-03755-1

Rieley, G., Dover, C. L. V., Hedrick, D. B., and Eglinton, G. (1999). Trophic ecology of Rimicaris exoculata?: a combined lipid abundance/stable isotope approach. Mar. Biol. 133, 495-499. doi: 10.1007/s002270050489

Rogers, A. D., Tyler, P. A., Connelly, D. P., Copley, J. T., James, R., Larter, R. D., et al. (2012). The Discovery of new deep-sea hydrothermal vent communities in the Southern Ocean and implications for biogeography. PLoS Biol. 10:e1001234. doi: 10.1371/journal.pbio.1001234

Roterman, C. N., Copley, J. T., Linse, K. T., Tyler, P. A., and Rogers, A. D. (2013). The biogeography of the yeti crabs (Kiwaidae) with notes on the phylogeny of the Chirostyloidea (Decapoda: Anomura). Proc. R. Soc. B Biol. Sci. 280:20130718. doi: 10.1098/rspb.2013.0718

Sarrazin, J., Juniper, S. K., Massoth, G., and Legendre, P. (1999). Physical and chemical factors influencing species distributions on hydrothermal sulfide edifices of the Juan de Fuca Ridge, northeast Pacific. Mar. Ecol. Prog. Ser. 190, 89-112.

Sarrazin, J., Legendre, P., de Busserolles, F., Fabri, M.-C., Guilini, K., Ivanenko, V. N., et al. (2015). Biodiversity patterns, environmental drivers and indicator species on a high-temperature hydrothermal edifice, Mid-Atlantic Ridge. Deep Sea Res. Part II Top. Stud. Oceanogr. 121, 177-192. doi: 10.1016/j.dsr2.2015.04. 013

Sarrazin, J., Robigou, V., Juniper, S., and Delaney, J. (1997). Biological and geological dynamics over four years on a high-temperature sulfide structure at the Juan de Fuca Ridge hydrothermal observatory. Mar. Ecol. Prog. Ser. 153, $5-24$.

Schmid-Araya, J. M., and Schmid, P. E. (2000). Trophic relationships: integrating meiofauna into a realistic benthic food web. Freshw. Biol. 44, 149-163. doi: 10.1046/j.1365-2427.2000.00594.x

Schratzberger, M., and Ingels, J. (2018). Meiofauna matters: The roles of meiofauna in benthic ecosystems. J. Exp. Mar. Biol. Ecol. 502, 12-25. doi: 10.1016/j.jembe. 2017.01.007

Scotese, C. R., and Wright, N. (2018). PALEOMAP paleodigital elevation models (PaleoDEMS) for the Phanerozoic. Available online at: https://www.earthbyte. org/paleodem-resource-scotese-and-wright-2018 (accessed August 19, 2018)

Shank, T. M., Fornari, D. J., Von Damm, K. L., Lilley, M. D., Haymon, R. M., and Lutz, R. A. (1998). Temporal and spatial patterns of biological community development at nascent deep-sea hydrothermal vents $\left(9^{\circ} 50^{\prime} \mathrm{N}\right.$, East Pacific Rise). Deep Sea Res. Part II Top. Stud. Oceanogr. 45, 465-515. doi: 10.1016/ S0967-0645(97)00089-1

Sigwart, J. D., Chen, C., Thomas, E. A., Allcock, A. L., Böhm, M., and Seddon, M. (2019). Red Listing can protect deep-sea biodiversity. Nat. Ecol. Evolut. 3, 1134-1134. doi: 10.1038/s41559-019-0930-2

Sigwart, J., Chen, C., and Elin, T. (2019). IUCN Red List of Threatened Species: Chrysomallon squamiferum. IUCN Red List of Threatened Species. Gland: IUCN.

Snow, J. E., and Edmonds, H. N. (2007). Ultraslow-spreading ridges rapid paradigm changes. Oceanography 20, 90-101. doi: 10.5670/oceanog.2007.83
Stein, J. L., Cary, S. C., Hessler, R. R., Vetter, R. D., Felbeck, H., Ohta, S., et al. (1988). Chemoautotrophic symbiosis in a hydrothermal vent gastropod. Biol. Bull. 174, 373-378. doi: 10.2307/1541963

Sun, J., Zhou, Y., Chen, C., Kwan, Y. H., Sun, Y., Wang, X., et al. (2020). Nearest vent, dearest friend: biodiversity of Tiancheng vent field reveals cross-ridge similarities in the Indian Ocean. R. Soc. Open Sci. 7:200110. doi: 10.1098/rsos. 200110

Sweetman, A., Levin, L., Rapp, H., and Schander, C. (2013). Faunal trophic structure at hydrothermal vents on the southern Mohn's Ridge, Arctic Ocean. Mar. Ecol. Prog. Ser. 473, 115-131. doi: 10.3354/meps 10050

Tao, C., Seyfried, W. E., Lowell, R. P., Liu, Y., Liang, J., Guo, Z., et al. (2020). Deep high-temperature hydrothermal circulation in a detachment faulting system on the ultra-slow spreading ridge. Nat. Commun. 11:1300. doi: 10.1038/s41467020-15062-w

Tao, C., Wu, G., Ni, J., Zhao, H., Su, X., Zhou, N., et al. (2009). New hydrothermal fields found along the SWIR during the Legs 5-7 of the Chinese DY115-20 Expedition. AGU Fall Meeting Abstracts 21, 21A-1150A.

Teixeira, S., Serrão, E. A., and Arnaud-Haond, S. (2012). Panmixia in a fragmented and unstable environment: The hydrothermal shrimp Rimicaris exoculata disperses extensively along the Mid-Atlantic Ridge. PLoS One 7:e38521. doi: 10.1371/journal.pone.0038521

Thomson, R. E., Mihály, S. F., Rabinovich, A. B., McDuff, R. E., Veirs, S. R., and Stahr, F. R. (2003). Constrained circulation at Endeavour ridge facilitates colonization by vent larvae. Nature 424, 545-549. doi: 10.1038/nature01824

Thornburg, C. C., Zabriskie, T. M., and McPhail, K. L. (2010). Deep-sea hydrothermal vents: Potential hot spots for natural products discovery? J. Nat. Prod. 73, 489-499. doi: 10.1021/np900662k

Tsurumi, M. (2003). Diversity at hydrothermal vents. Glob. Ecol. Biogeogr. 12, 181-190. doi: 10.1046/j.1466-822X.2003.00016.x

Tunnicliffe, V. (1988). Biogeography and evolution of hydrothermal-vent fauna in the eastern Pacific Ocean. Proc. R. Soc. London B Biol. Sci. 233, 347-366. doi: 10.1098/rspb.1988.0025

Urcuyo, I. A., Bergquist, D. C., MacDonald, I. R., VanHorn, M., and Fisher, C. R. (2007). Growth and longevity of the tubeworm Ridgeia piscesae in the variable diffuse flow habitats of the Juan de Fuca Ridge. Mar. Ecol. Prog. Ser. 344, 143-157.

Van Dover, C. L. (2002). Trophic relationships among invertebrates at the Kairei hydrothermal vent field (Central Indian Ridge). Mar. Biol. 141, 761-772. doi: 10.1007/s00227-002-0865-y

Van Dover, C. L. (2019). Inactive sulfide ecosystems in the deep sea: A review. Front. Mar. Sci. 6:00461. doi: 10.3389/fmars.2019.00461

Van Dover, C. L., Arnaud-Haond, S., Gianni, M., Helmreich, S., Huber, J. A., Jaeckel, A. L., et al. (2018). Scientific rationale and international obligations for protection of active hydrothermal vent ecosystems from deep-sea mining. Mar. Policy 90, 20-28. doi: 10.1016/j.marpol.2018.01.020

Van Dover, C. L., Colaço, A., Collins, P. C., Croot, P., Metaxas, A., Murton, B. J., et al. (2020). Research is needed to inform environmental management of hydrothermally inactive and extinct polymetallic sulfide (PMS) deposits. Mar. Policy 121:104183. doi: 10.1016/j.marpol.2020.104183

Van Dover, C. L., Grassle, J. F., and Boudrias, M. (1990). Hydrothermal vent fauna of Escanaba Trough (Gorda Ridge). SpringerLink 1990, 285-287. doi: 10.1007/978-1-4612-3258-2_21

Van Dover, C. L., Humphris, S. E., Fornari, D., Cavanaugh, C. M., Collier, R., Goffredi, S. K., et al. (2001). Biogeography and ecological setting of Indian Ocean hydrothermal vents. Science 294, 818-823. doi: 10.1126/science.1064574

Vereshchaka, A. L., Vinogradov, G. M., Lein, A. Yu, Dalton, S., and Dehairs, F. (2000). Carbon and nitrogen isotopic composition of the fauna from the Broken Spur hydrothermal vent field. Mar. Biol. 136, 11-17. doi: 10.1007/ s002270050002

Vrijenhoek, R. C. (1997). Gene flow and genetic diversity in naturally fragmented metapopulations of deep-sea hydrothermal vent animals. J. Hered. 88, 285-293. doi: 10.1093/oxfordjournals.jhered.a023106

Wang, Y., Han, X., Petersen, S., Frische, M., Qiu, Z., Li, H., et al. (2017). Mineralogy and trace element geochemistry of sulfide minerals from the Wocan Hydrothermal Field on the slow-spreading Carlsberg Ridge, Indian Ocean. Ore Geol. Rev. 84, 1-19. doi: 10.1016/j.oregeorev.2016.12.020 
Wang, Y., Han, X., Zhou, Y., Qiu, Z., Yu, X., Petersen, S., et al. (2021). The Daxi Vent Field: An active mafic-hosted hydrothermal system at a nontransform offset on the slow-spreading Carlsberg Ridge, $6^{\circ} 48^{\prime} \mathrm{N}$. Ore Geol. Rev. 129:103888. doi: 10.1016/j.oregeorev.2020.103888

Wang, Z., Xu, T., Zhang, Y., Zhou, Y., Liu, Z., Chen, C., et al. (2020). Molecular phylogenetic and morphological analyses of the 'monospecific' Hesiolyra (Annelida: Hesionidae) reveal two new species. Deep Sea Res. Part I Oceanogr. Res. Papers 166:103401. doi: 10.1016/j.dsr.2020.103401

Washburn, T. W., Turner, P. J., Durden, J. M., Jones, D. O. B., Weaver, P., and Van Dover, C. L. (2019). Ecological risk assessment for deep-sea mining. Ocean Coastal Manage. 176, 24-39. doi: 10.1016/j.ocecoaman.2019.04.014

Watanabe, H. K., Chen, C., Marie, D. P., Takai, K., Fujikura, K., and Chan, B. K. K. (2018). Phylogeography of hydrothermal vent stalked barnacles: a new species fills a gap in the Indian Ocean 'dispersal corridor' hypothesis. R. Soc. Open Sci. 5:172408. doi: 10.1098/rsos.172408

Watanabe, H., and Beedessee, G. (2015). “"Vent fauna on the Central Indian Ridge,", in Subseafloor Biosphere Linked to Hydrothermal Systems: TAIGA Concept, eds J. Ishibashi, K. Okino, and M. Sunamura (Tokyo: Springer Japan), 205-212. doi: 10.1007/978-4-431-54865-2_16

Won, Y.-J., Hallam, S. J., O’Mullan, G. D., Pan, I. L., Buck, K. R., and Vrijenhoek, R. C. (2003). Environmental acquisition of thiotrophic endosymbionts by deep-sea mussels of the genus Bathymodiolus. Appl. Environ. Microbiol. 69, 6785-6792. doi: 10.1128/AEM.69.11.6785-6792.2003

Xu, W., Gong, L., Pang, K.-L., and Luo, Z.-H. (2018). Fungal diversity in deep-sea sediments of a hydrothermal vent system in the Southwest Indian Ridge. Deep Sea Res. Part I Oceanogr. Res. Papers 131, 16-26. doi: 10.1016/j.dsr.2017.11.001

Yahagi, T., Watanabe, H., Shigeaki, K., and Yasunori, K. (2017). Do larvae from deep-sea hydrothermal vents disperse in surface waters? Ecology 98, 1524-1534. doi: 10.1002/ecy.1800

Yamanaka, T., Mizota, C., Fujiwara, Y., Chiba, H., Hashimoto, J., Gamo, T., et al. (2003). Sulphur-isotopic composition of the deep-sea mussel Bathymodiolus marisindicus from currently active hydrothermal vents in the Indian Ocean. J. Mar. Biol. Associat. U K 83, 841-848. doi: 10.1017/S0025315403007872h

Yang, Y., Sun, J., Chen, C., Zhou, Y., Lan, Y., Dover, C. L. V., et al. (2020). Tripartite holobiont system in a vent snail broadens the concept of chemosymbiosis. bioRxiv [Preprint]:295170. doi: 10.1101/2020.09.13 295170

Yang, Z., Xiao, X., and Zhang, Y. (2020). Microbial diversity of sediments from an inactive hydrothermal vent field, Southwest Indian Ridge. Mar. Life Sci. Technol. 2, 73-86. doi: 10.1007/s42995-019-00007-0

Zbinden, M., Shillito, B., Le Bris, N., de Montlaur, C. D. V., Roussel, E., Guyot, F., et al. (2008). New insigths on the metabolic diversity among the epibiotic microbial communitiy of the hydrothermal shrimp Rimicaris exoculata. J. Exp. Mar. Biol. Ecol. 359, 131-140. doi: 10.1016/j.jembe.2008.03.009

Zekely, J., Van Dover, C. L., Nemeschkal, H. L., and Bright, M. (2006). Hydrothermal vent meiobenthos associated with mytilid mussel aggregations from the Mid-Atlantic Ridge and the East Pacific Rise. Deep Sea Res. Part I Oceanogr. Res. Papers 53, 1363-1378. doi: 10.1016/j.dsr.2006.05.010

Zhou, Y., Zhang, D., Zhang, R., Liu, Z., Tao, C., Lu, B., et al. (2018). Characterization of vent fauna at three hydrothermal vent fields on the Southwest Indian Ridge: Implications for biogeography and interannual dynamics on ultraslow-spreading ridges. Deep Sea Res. Part I Oceanogr. Res. Pap. 137, 1-12. doi: 10.1016/j.dsr.2018.05.001

Conflict of Interest: The authors declare that the research was conducted in the absence of any commercial or financial relationships that could be construed as a potential conflict of interest.

Publisher's Note: All claims expressed in this article are solely those of the authors and do not necessarily represent those of their affiliated organizations, or those of the publisher, the editors and the reviewers. Any product that may be evaluated in this article, or claim that may be made by its manufacturer, is not guaranteed or endorsed by the publisher.

Copyright (C) 2021 Perez, Sun, Xu and Qian. This is an open-access article distributed under the terms of the Creative Commons Attribution License (CC BY). The use, distribution or reproduction in other forums is permitted, provided the original author(s) and the copyright owner(s) are credited and that the original publication in this journal is cited, in accordance with accepted academic practice. No use, distribution or reproduction is permitted which does not comply with these terms. 